$\underline{\underline{\beta}}=-m$

\title{
Hepatoprotective activity of the methanolic leaf extract of Moringa oleifera (Lam) against chemically-induced Liver Toxicity
}

\author{
*Mbagwu, Herbert Orji Chidi; Etok, Nsikan Jimmy and Ekpo, EmemUmoh \\ Department of Pharmacology and Toxicology, Faculty of Pharmacy, University of Uyo, P.M.B. 1017 Uyo, Nigeria \\ *Corresponding author E-mail:hermba2006@yahoo.com
}

\begin{abstract}
Aim: Moringa oleifera commonly known as "miracle plant" possesses enormous nutritional and medicinal properties. It is used in traditional medicine in treating many ailments, including liver disorders. Though some works on hepatoprotective effects have been done (Mishra et al., 2011), the present study aims at evaluating the methanolic leaf extract (MLE) of Moringa oleifera harvested in Ewet Housing Estate in Uyo; AkwaIbom State in South-South Nigeria.
\end{abstract}

Materials and Methods: The Carbon tetrachloride $\left(\mathrm{CCl}_{4}\right)$ model was employed throughout this investigation (Dongare et al., 2013). Briefly, thirty animals were randomly divided into six groups of five animals in each group. Group I served as normal control and was administered $10 \mathrm{ml} / \mathrm{kg}$ normal saline. Group II was the toxic control and received $3 \mathrm{ml} / \mathrm{kg}$ of CCl 4 . Group III served as the reference control and received $100 \mathrm{mg} / \mathrm{kg}$ silymarin while groups IV, V and VI received 9, 18 and $27 \mathrm{mg} / \mathrm{kg}$ of MLE respectively. Phytochemical screening, acute toxicity tests as well as free radical scavenging effects using DPPH (in vitro) were also carried out.

Results: Preliminary phytochemical tests revealed the presence of tannins, flavonoids, alkaloids, anthraquinones, saponins, terpenes, phlobatanins and cardiac glycosides. The acute toxicity investigations showed that MLE $\mathrm{LD}_{50}$ was $90 \mathrm{mg} / \mathrm{kg}$. In the hepatoprotective studies, liver function tests $(\mathrm{LFT})$ revealed a significant $(\mathrm{p}<0.05)$ protective effect when compared with silymarin. The histopathological studies also provided supportive evidence for the protective effects of MLE. The DPPH studies showed that MLE has antioxidant property.

Conclusion: It can be concluded based on findings from this study that the MLE of Moringa oleifera possesses antioxidant and hepatoprotective activities in a dose-dependent manner and safe for oral administration.

Keywords: Antioxidant; carbon tetrachloride; hepatitis; necrosis; silymarin.

\section{Introduction}

The liver is the main organ where exogenous chemicals are metabolized and eventually excreted. Owing to its strategic anatomical location, it is exposed to many xenobiotics including therapeutic agents (Chatterjee, 2000). This can cause liver dysfunction, cell injury and even organ failure.

About 20,000 deaths recorded every year have been ascribed to liver disorders (Gupta et al., 2006). Treatment options for common liver diseases such as liver cirrhosis, fatty liver and chronic hepatitis are problematic. Physicians and patients are in need of effective therapeutic agents with low incidence of side effects. Liver disease is still a worldwide health problem. Unfortunately, conventional or synthetic drugs used for the treatment of liver diseases are inadequate and sometimes can have serious side effects (Gupta, 2006). In spite of tremendous advances in modern medicine, no effective drugs are available, which stimulate liver functions and offer protection to the liver from the damage or help to regenerate hepatic cells (Panda, 2009). In the absence of a reliable liver-protective drug in modern medicine, a study on this "wonder plant" Moringa oleifera is pertinent.

The plant kingdom represents a rich store house of organic compounds, many of which have been used for medicinal purposes and could serve as lead for the development of novel agents having good efficacy in various pathological disorders in the coming years (Goyal et al., 2007). This suggests that, in principle, most plants have a potential medicinal value. Medicinal plants have been considered as important therapeutic aids for alleviating ailments of humankind. About $80 \%$ of the world population relies on the use of traditional medicine, which is predominantly based on plant materials (Singh et al., 2013). Traditional medicine practitioners in various parts around the world have used Moringa in their herbal medicine repertoire for ailments ranging from gastrointestinal problems, to veneral diseases and inflammations as well as to treat liver and renal disorders, etc., thus earning the plant names such as "miracle tree" "wonder tree" "mother best friend" (Ganatra et al., 2012).

\section{Materials and methods}

\subsection{Plant collection and identification}

Fresh leaves of Moringa oleifera were collected from Ewet Housing Estate in Uyo Local Government Area of Akwa Ibom State, Nigeria in November, 2014. The plant material was identified and authenticated by Dr. (Mrs.) Margaret Bassey, a plant 
Taxonomist in the Department of Botany and Ecological Studies, University of Uyo, Uyo. A voucher specimen A (50)i was deposited in the herbarium of the Faculty of Pharmacy, University of Uyo.

\subsection{Preparation of extract}

The leaves were sun dried for seven days. The dried leaves were pulverized to powder, weighed and macerated in $60 \%$ methanol for 72 hours. The filtrate obtained was concentrated and evaporated to dryness using water bath. The dried extract was preserved in the refrigerator until required for use. The yield of the extract was calculated to be $10.93 \% \mathrm{w} / \mathrm{w}$.

\subsection{Phytochemical screening of extract}

The crude methanol extracts were subjected to phytochemical screening using standard procedures (Trease and Evans, 2002).

\subsection{Determination of Median Lethal Dose}

The Up-and-Down procedure (UDP)-OECD TG 425 was used to determine the $\mathrm{LD}_{50}$. This method uses death as an endpoint, but doses animals one at a time to see if the dose needs to be put up or down to achieve an estimate of the $\mathrm{LD}_{50}$ therefore, giving the minimum number of animals a lethal dose of the test substance (Paramveer, 2010). In the Up-and-Down procedure, animals are dosed one at a time. If an animal survives, the dose for the next animal is increased; if it dies, the dose is decreased. Each animal was observed for $24 \mathrm{~h}$. briefly, doses of the extract (20-2000 $\mathrm{mg} / \mathrm{kg}$ ) were administered intraperitoneally (i.p) to the mice and signs of physical toxicity were observed. The $\mathrm{LD}_{50}$ was determined from this. Swiss albino mice were used for this study.

\subsection{Experimental design}

\section{a) Hepatoprotective studies:}

Thirty (30) animals were randomly divided into six (6) groups with five (5) animals in each group. They were treated as described below:

Group I (Normal Control): Normal saline $(10 \mathrm{ml} / \mathrm{kg}$ ) was administered orally for eight (8) days.

Group II (Toxic Control): Normal saline $(10 \mathrm{ml} / \mathrm{kg}$ ) was administered orally for seven (7) days. On the eighth day, $(3 \mathrm{ml} / \mathrm{kg})$ of $\mathrm{CCl}_{4}$ was administered intraperitoneally (i.p).

Group III (Reference Control): Silymarin (100mg/kg) was administered orally for seven (7) days. On the eighth day, $(3 \mathrm{ml} / \mathrm{kg})$ of $\mathrm{CCl}_{4}$ was administered intraperitoneally (i.p).

Groups IV, Group V and Group VI received 9, 18 and $27 \mathrm{mg} / \mathrm{kg}$ of MLE orally for seven (7) days. On the eighth day, $(3 \mathrm{ml} / \mathrm{kg})$ of $\mathrm{CCl}_{4}$ were administered intraperitoneally (i.p).

On the ninth day and 24 hours after the $\mathrm{CCl}_{4}$ administration, each animal was weighed and then sacrificed under chloroform anesthesia. Blood samples were collected for biochemical analysis. Liver tissues were obtained for histopathological analysis.

b) Antioxidant Studies

The free-radicalscavenging activity of Moringa oleifera methanolic leaf extracts was measured by 1, 1-diphenyl-2-picryl-hydrazil (DPPH) using the method of Blois (1958) with slight modification. Briefly, $2 \mathrm{ml}$ of DPPH solution $(0.004 \%$ in methanol) was incubated with $2 \mathrm{ml}$ of extract at various concentrations (20-100 $\mu \mathrm{g} / \mathrm{ml})$. The reaction mixture was shaken and incubated at room temperature for 30 minutes in the dark. The control was prepared as above without extract. The absorbance of the solution was measured at $517 \mathrm{~nm}$ against a blank. Vitamin C (ascorbic acid) was used as reference standard. The DPPH radical scavenging activity was calculated according to the following equation.

$(\%$ inhibition $)=\left\{\left(\mathrm{A}_{0}-\mathrm{A}_{1}\right) / \mathrm{A}_{0}\right\} \times 100$

Where $A_{0}$ was the absorbance of the control reaction (DPPH) alone and $\mathrm{A}_{1}$ was the absorbance in the presence of the sample (extract or vitamin $\mathrm{C}$ ).

The $\mathrm{IC}_{50}$ value denotes the concentration of sample required to scavenge $50 \%$ of DPPH free radicals.

\subsection{Statistical analysis}

Data were expressed as mean \pm SEM. Statistical comparisons between groups were performed using analysis of variance (ANOVA). Differences between Means were determined by Tukey-Kramer pair-wise comparison test at a level of significance $\mathrm{p}<0.05$.

\section{Results}

The phytochemical screening results show that Moringa oleifera leaf extract contains flavonoids, tannins, saponins, alkaloids, phlobatanins, terpenes and cardiac glycocides. Free and combined anthraquinones were absent. They are as presented in table 1 .

The median lethal dose $\left(\mathrm{LD}_{50}\right)$ in mice following oral administration was calculated to be $90 \mathrm{mg} / \mathrm{kg}$. The physical signs of toxicity included writhing, decreased respiratory rate, decreased motor activity and death within $24 \mathrm{~h}$.

The results of the biochemical analysis are presented in table 2 and figures 1 to 5 . The administration of $\mathrm{CCl}_{4}(3 \mathrm{ml} / \mathrm{kg})$ evoked significant $(p<0.05-0.001)$ elevations in serum levels of biomarker enzymes such as alanine aminotransferase (ALT), aspartate aminotransferase (AST) and alkaline phosphatase (ALP) when compared with the normal control. The pretreatment of rats with MLE $(9,18$ and $27 \mathrm{mg} / \mathrm{kg})$ significantly $(\mathrm{p}<0.05-0.001)$ mitigated these elevations in a dose-dependent manner. Similarly, pretreatment of rats with MLE (9, 18 and $27 \mathrm{mg} / \mathrm{kg}$ ) attenuated the significant elevations $(\mathrm{p}<0.05-0.001)$ in total and conjugated bilirubin levels. The protection produced by $27 \mathrm{mg} / \mathrm{kg}$ of MLE was comparable to silymarin $(100 \mathrm{mg} / \mathrm{kg})$.

The effects of MLE on free radical scavenging activity using DPPH in vitro are presented in tables 3 and 4 as well as figure 6 .

From the results the $\mathrm{IC}_{50}$ of the extract and vitamin $\mathrm{C}$ were determined to be 84.0 and $10.8 \mu \mathrm{g} / \mathrm{ml}$ respectively. The extract produced a concentration-dependent free radical scavenging activity. The results of the activity of MLE on the histology of the liver are presented in Table 5. In the histopathological examination of the liver tissue the negative control showed normal architecture, no steatosis, mild portal inflammation, mild congested sinusoids, no necrosis and no fibrosis (Fig. 6) whereas the toxic control showed distorted architecture, focal necrosis, severe steatosis/portal inflammation with interphase hepatitis/congested sinusoids and no fibrosis (Fig. 7). Treatment with Silymarin $100 \mathrm{mg} / \mathrm{kg}$ showed improved architecture compared to the toxic control, decreased steatosis/necrosis/portal inflammation but no interphase hepatitis, mild to moderate congested sinusoids and no fibrosis (Fig. 8). Treatment with $9 \mathrm{mg} / \mathrm{kg}$ of extract showed mildly distorted architecture, mild focal necrosis/portal inflammation/congested sinusoids, mild to moderate steatosis and no fibrosis (Fig. 9). Treatment with $18 \mathrm{mg} / \mathrm{kg}$ of extract showed mildly distorted architecture, mild microvesicularsteatosis, moderate portal inflammation, mild congested sinusoids and no focal necrosis/fibrosis (Fig. 10). Treatment with $27 \mathrm{mg} / \mathrm{kg}$ of extract showed mildly distorted architecture, mild microvesicularsteatosis, mild congested sinusoids and no focal necrosis/portal inflammation/fibrosis (Fig. 11). 
Table 1: Phytochemical Screening of Methanol Leaf Extract of Moringa Oleifera.

\begin{tabular}{lll}
\hline & Tests & Inference \\
\hline 1 & Alkaloids & +++ \\
2 & Tannins & +++ \\
3 & Saponins & + \\
4 & Flavonoids & ++ \\
5 & Phlobatanins & ++ \\
6 & Terpenes & ++ \\
7 & Cardiac glycoside & ++ \\
8 & Free \& combine anthraquinones & + \\
\hline Key: + Trace ++ Positive +++ stronglypositive, Negative
\end{tabular}

Key: + Trace, ++ Positive, +++ stronglypositive, - Negative

Table 2: Effect of MLE on Biochemical Parameters

\begin{tabular}{|c|c|c|c|c|c|c|}
\hline TREATMENT & & PARAMETERS & & & & \\
\hline Groups & Doses & $\begin{array}{l}\text { AST. } \\
\text { IU/L }\end{array}$ & $\begin{array}{l}\text { ALT. } \\
\text { IU/L }\end{array}$ & $\begin{array}{l}\text { ALP. } \\
\text { IU/L }\end{array}$ & $\begin{array}{l}\text { Total Bil. } \\
\mathrm{mMol} / \mathrm{L}\end{array}$ & $\begin{array}{l}\text { Conju. Bil. } \\
\text { mMol/L }\end{array}$ \\
\hline $\begin{array}{l}\text { Normal } \\
\text { control }\end{array}$ & $\begin{array}{l}10 \mathrm{ml} / \mathrm{kg} \text { Nor- } \\
\mathrm{mal} \text { saline (NS) }\end{array}$ & $10.66 \pm 2.02$ & $9.33 \pm 0.66$ & $24.6 \pm 0.36$ & $21.7 \pm 0.60$ & $9.0 \pm 0.40$ \\
\hline Toxic control & $\begin{array}{l}10 \mathrm{ml} / \mathrm{kg} \mathrm{NS}+3 \\
\mathrm{ml} / \mathrm{kg} \mathrm{CCl}_{4}\end{array}$ & $29.0 \pm 2.64^{b}$ & $22.66 \pm 1.76^{\mathrm{c}}$ & $44.8 \pm 0.90^{c}$ & $37.56 \pm 2.22^{\mathrm{c}}$ & $27.96 \pm 0.34^{\mathrm{c}}$ \\
\hline Ref. control & $\begin{array}{l}100 \mathrm{mg} / \mathrm{kg} \mathrm{Si}- \\
\text { lymarin }+ \\
3 \mathrm{ml} / \mathrm{kg} \mathrm{CCl}_{4}\end{array}$ & $20.0 \pm 4.72^{\mathrm{n}^{\mathrm{se}}}$ & $10.0 \pm 2.51^{\mathrm{e}}$ & $25.0 \pm 0.45^{\mathrm{f}}$ & $24.2 \pm 0.01^{\mathrm{f}}$ & $8.6 \pm 0.96^{\mathrm{f}}$ \\
\hline MLE1 & $\begin{array}{l}9 \mathrm{mg} / \mathrm{kg}+3 \\
\mathrm{ml} / \mathrm{kg} \mathrm{CCl} \mathrm{Cl}_{4}\end{array}$ & $18.0 \pm 1.46^{\mathrm{n}^{\mathrm{sd}}}$ & $15.0 \pm 1.31^{\mathrm{d}}$ & $24.23 \pm 0.32^{\mathrm{f}}$ & $30.4 \pm 2.19^{d}$ & $22.56 \pm 0.61^{\mathrm{ce}}$ \\
\hline MLE2 & $\begin{array}{l}18 \mathrm{mg} / \mathrm{kg}+3 \\
\mathrm{ml} / \mathrm{kg} \mathrm{CCl}\end{array}$ & $15.0 \pm 2.00^{\mathrm{n}^{\mathrm{pd}}}$ & $14.33 \pm 1.66^{\mathrm{d}}$ & $23.66 \pm 0.72^{f}$ & $27.3 \pm 1.76^{\mathrm{e}}$ & $15.92 \pm 1.34^{\mathrm{cf}}$ \\
\hline MLE3 & $\begin{array}{l}27 \mathrm{mg} / \mathrm{kg}+3 \\
\mathrm{ml} / \mathrm{kg} \mathrm{CCl}_{4}\end{array}$ & $11.33 \pm 3.66^{\mathrm{ns}^{\mathrm{e}}}$ & $11.66 \pm 2.33^{\mathrm{e}}$ & $25.9 \pm 1.15^{f}$ & $25.2 \pm 1.72^{f}$ & $12.13 \pm 1.63^{\mathrm{cf}}$ \\
\hline
\end{tabular}

Results Represent Mean \pm SEM

Values significant, $\mathrm{n}=5$

${ }^{\mathrm{a}} \mathrm{p}<0.05 ;{ }^{\mathrm{b}} \mathrm{p}<0.01 ;{ }^{\mathrm{e}} \mathrm{p}<0.001$ relative to control;

${ }^{\mathrm{d}} \mathrm{p}<0.05 ;{ }_{\mathrm{p}}^{\mathrm{p}}<0.01 ;{ }_{\mathrm{p}}^{\mathrm{f}}<0.001$ relative to $\mathrm{CCl}_{4}$

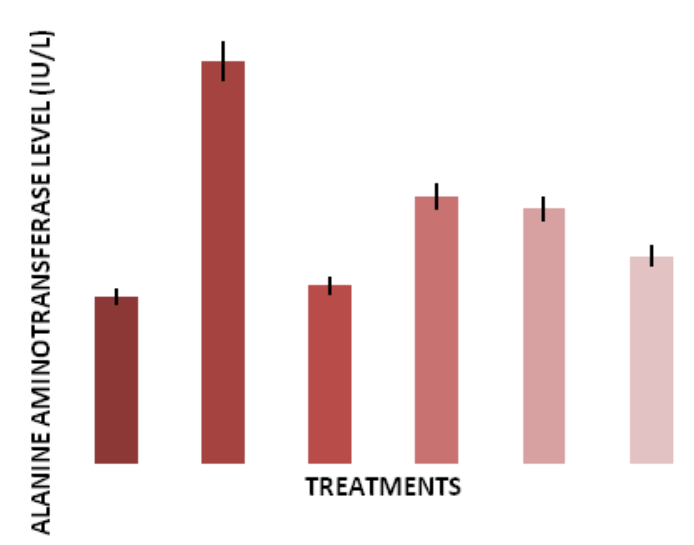

Fig. 1:Effect of Extract on Alanine Aminotransferase Level in Serum of Rats with $\mathrm{Ccl}_{4}$-Induced Hepatotoxicity

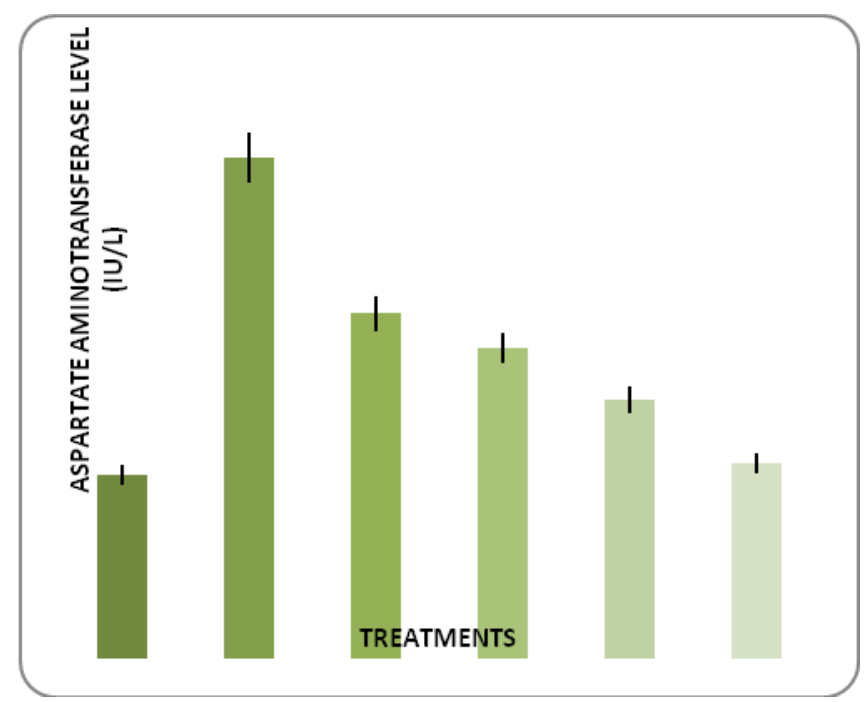

Fig.2:Effect of Extract on Aspartate Aminotransferase Level in Serum of Rats with $\mathrm{Ccl}_{4}$-Induced Hepatotoxicity 


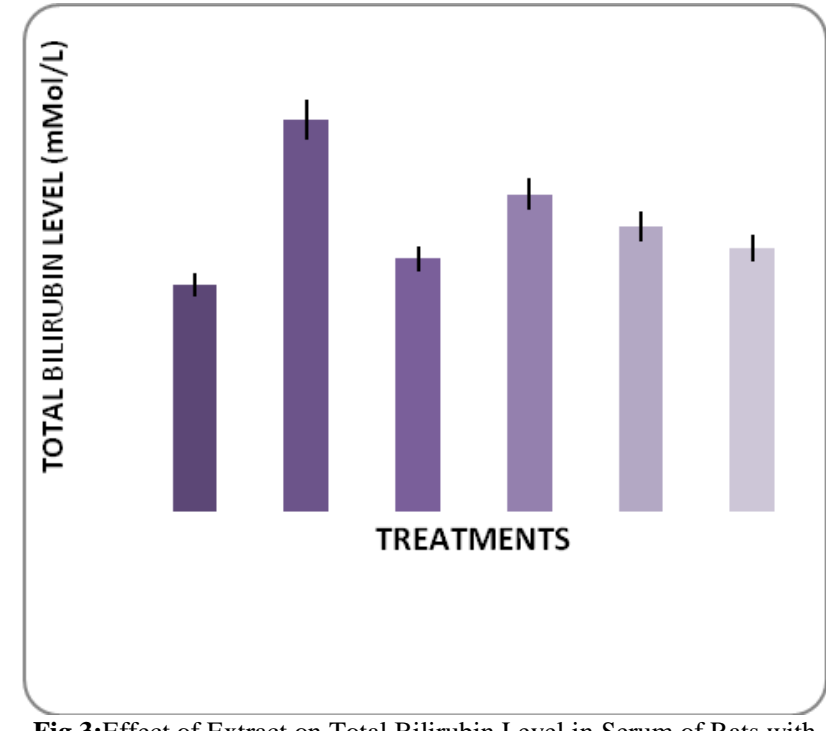

Fig.3:Effect of Extract on Total Bilirubin Level in Serum of Rats with $\mathrm{Ccl}_{4}$ - Induced Hepatotoxicity

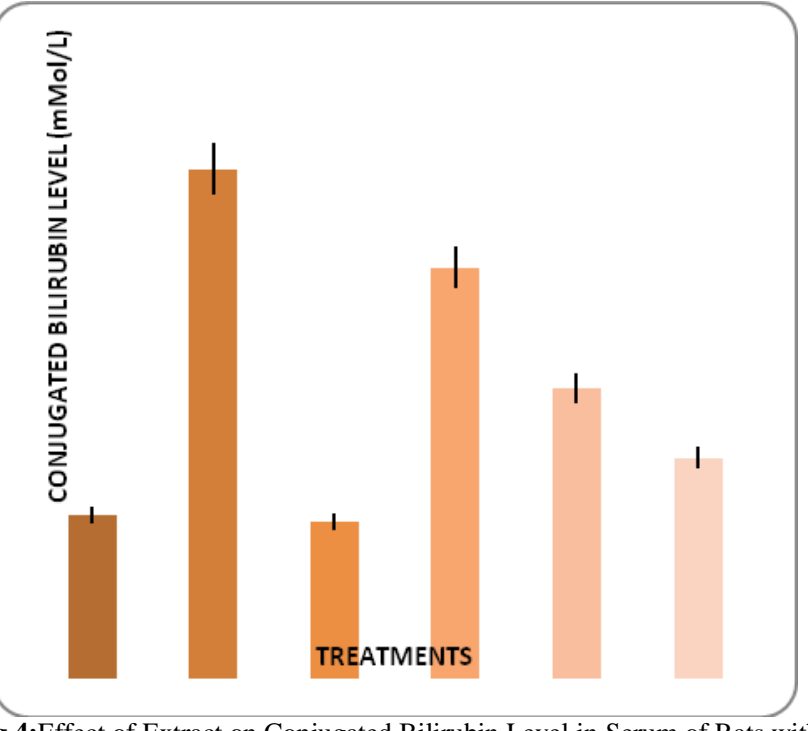

Fig.4:Effect of Extract on Conjugated Bilirubin Level in Serum of Rats with $\mathrm{Ccl}_{4}$-Induced Hepatotoxicity

Table 3: DPPH Free Radical Scavenging Activity of the Methanolic Leaf Extract of Moringa Oleifera

\begin{tabular}{llll}
\multicolumn{5}{c}{ Table 3: DPPH Free Radical Scavenging Activity of the Methanolic Leaf Extract of Moringa Oleifera } \\
\hline S/No. & Concentration $\mu \mathrm{g} / \mathrm{ml}$ & Absorbance & \% Inhibition DPPH \\
\hline 1 & 20 & 0.841 & 41.02 \\
2 & 40 & 0.772 & 45.86 \\
3 & 60 & 0.753 & 47.19 \\
4 & 80 & 0.729 & 48.88 \\
5 & 100 & 0.664 & 53.43 \\
& Blank & 1.426 & \\
\hline
\end{tabular}

Table 4: DPPH Free Radical Scavenging Activity of Vitamin C (Ascorbic Acid)

\begin{tabular}{llcc}
\multicolumn{4}{c}{ Table 4: DPPH Free Radical Scavenging Activity of Vitamin C (Ascorbic Acid) } \\
\hline S/No. & Concentration $\mu \mathrm{g} / \mathrm{ml}$ & Absorbance & \% Inhibition DPPH \\
\hline 1 & 20 & 0.094 & 93.41 \\
2 & 40 & 0.088 & 93.83 \\
3 & 60 & 0.087 & 93.89 \\
4 & 80 & 0.090 & 93.68 \\
5 & 100 & 0.084 & 94.11 \\
& Blank & 1.426 & \\
\hline
\end{tabular}

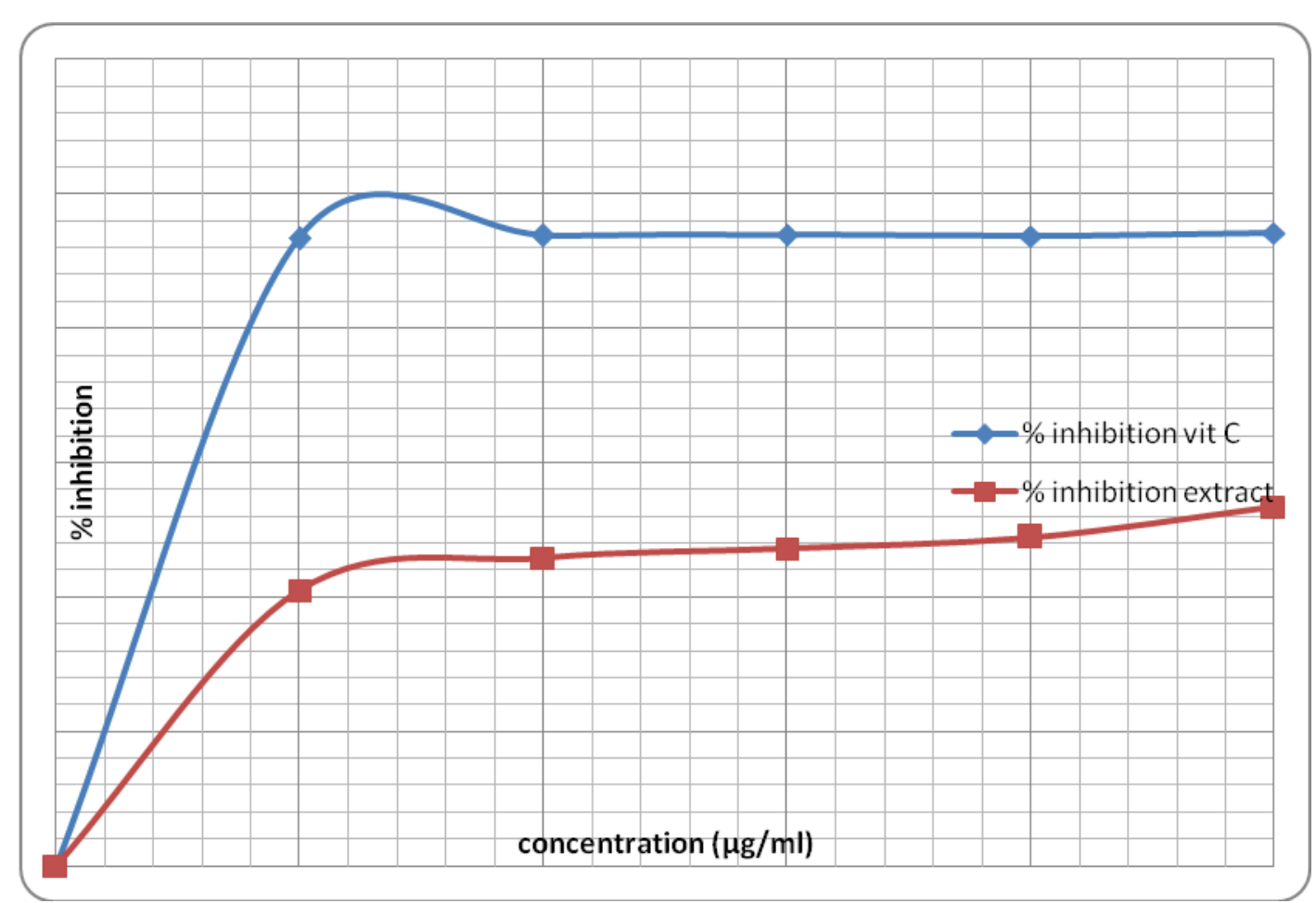

Fig. 5:The Percentage Inhibition-Concentration Curve of Extract Compared with Vitamin C (Ascorbic Acid). 


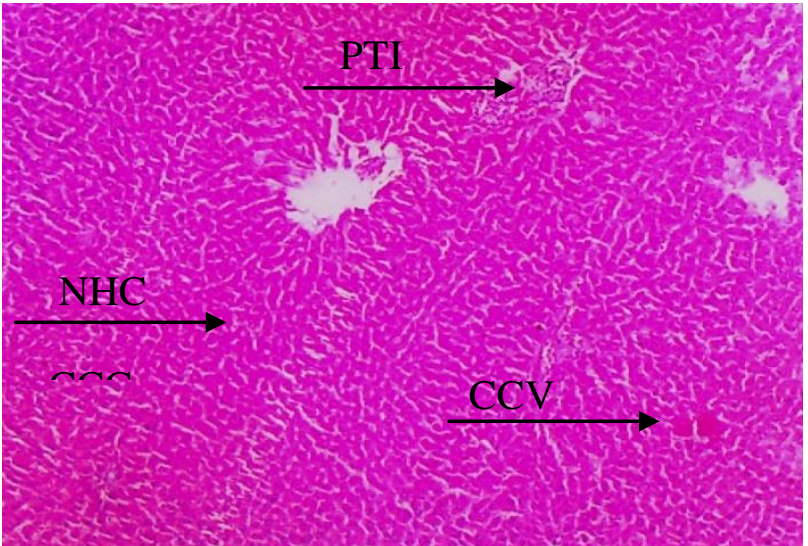

Fig. 6: Histologic Section of Rat Liver of Negative Control Showing Norma Hepatic Cells (NHC), Mild Congested Central Vein (CCV) and Mildly inflamed Portal Tract (IPT).

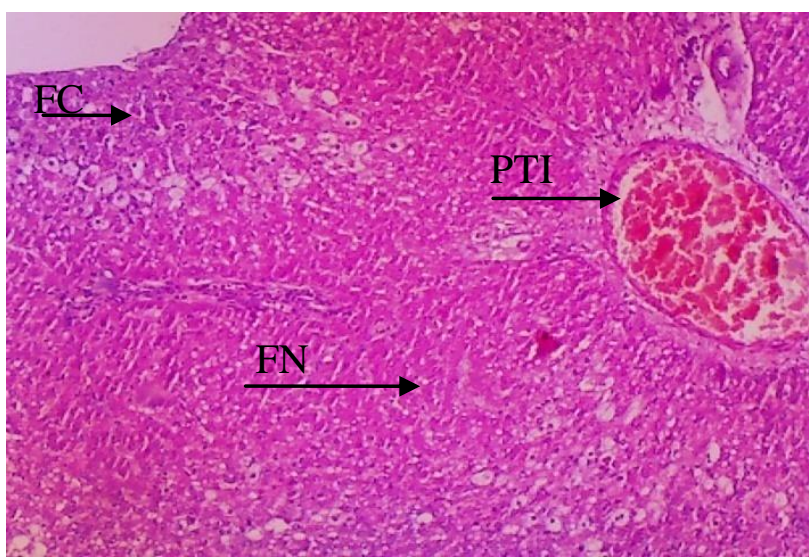

Fig. 8: Histologic Section of Rat Liver of Reference Control Showed Moderately Distorted Architecture of the Liver by Mild to Moderate Fatty

Change (FC), Decreased Focal Necrosis (FN) and Portal Tract Inflammation (PTI).

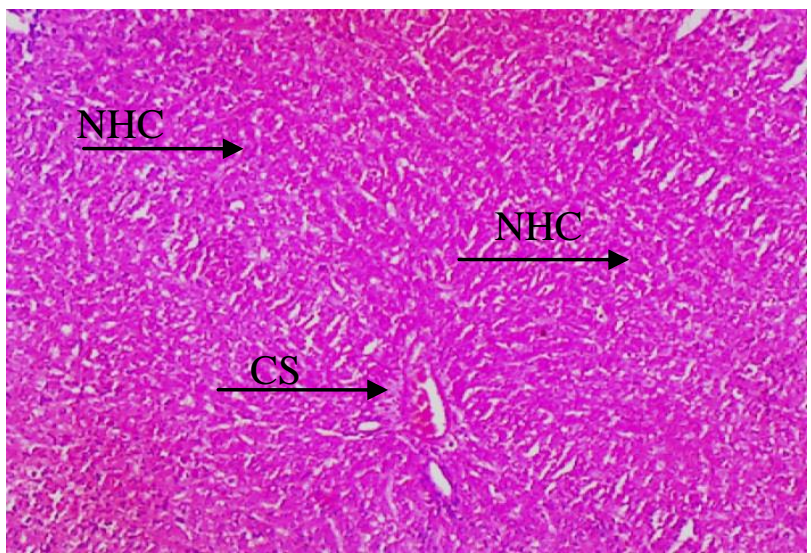

Fig. 10: Histologic Section of Rat Liver of $18 \mathrm{Mg} / \mathrm{Kg}$ of Moringa Leaf Extract Showed Almost Normal Architecture with Numerous Normal Hepatic Cells (NHC) and Congested Sinusoids (CS) as Well as Absence of Foca Necrosis and Fatty Changes.

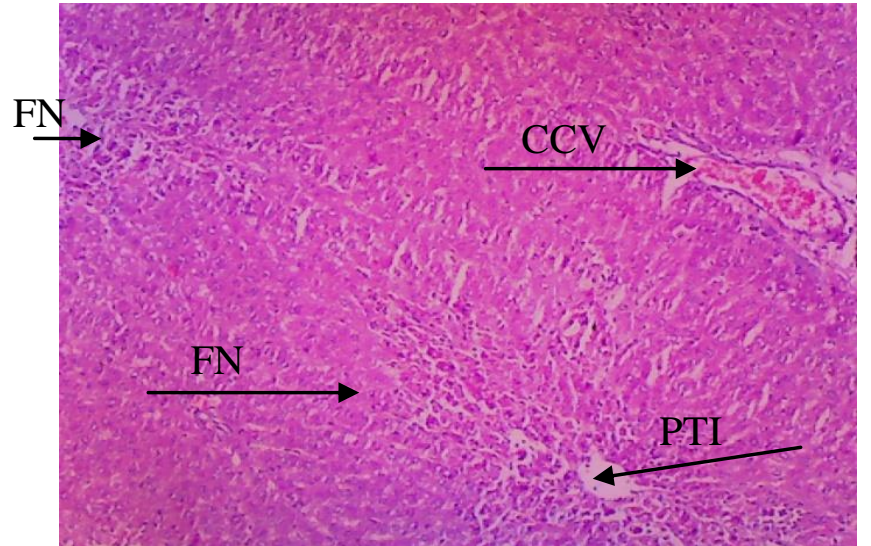

Fig. 7: Histologic Section of Rat Liver of Toxic Csontrol Showing Severely Distorted Architecture of the Liver by Severe Focal Necrosis (FN), Congested Central Vein (CCV) and Portal Tract Inflammation (PTI).

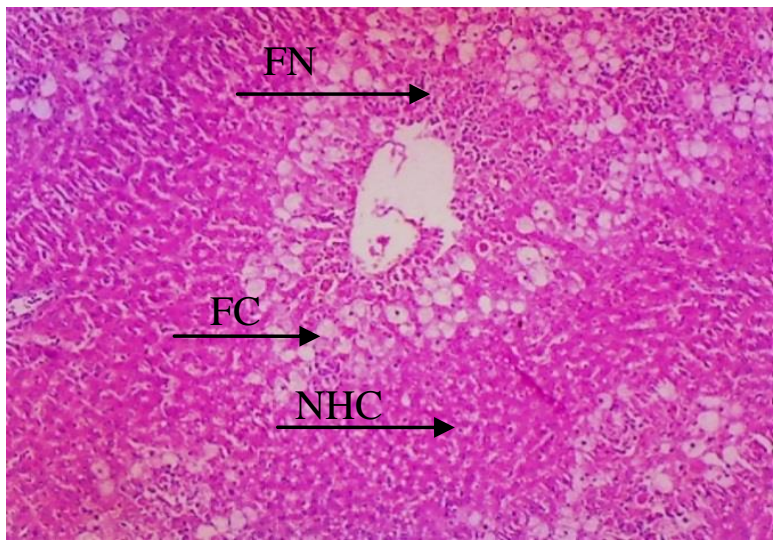

Fig. 9: Histologic Section of Rat Liver of $9 \mathrm{Mg} / \mathrm{Kg}$ of Moringa Leaf Extract Moderately Distorted Architecture by Mild Focal Necrosis (FN), Moderate Fatty Change (FC) And Numerous Hepatic Cells (NHC).

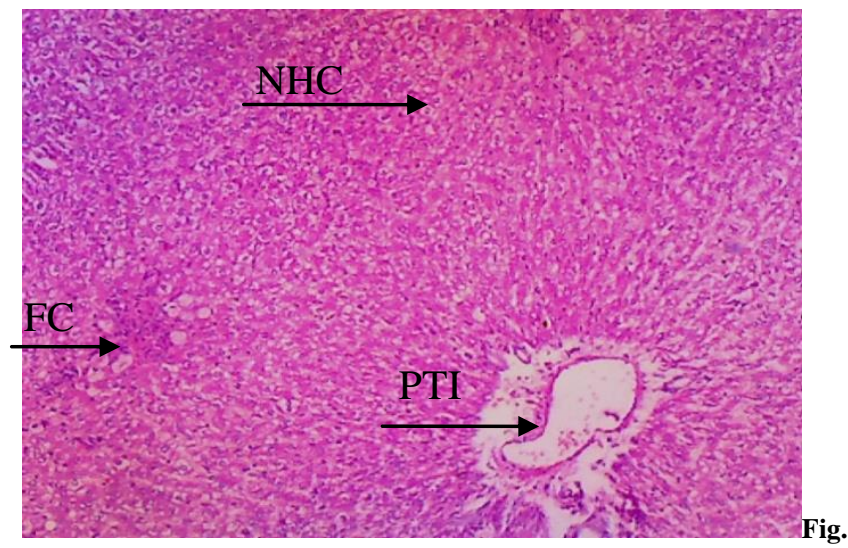

11: Histologic Section of Rat Liver of $27 \mathrm{Mg} / \mathrm{Kg}$ of Moringa Leaf Extract Showed Mildly Distorted Architecture by Mild Fatty Changes (FC) and Portal Tract Inflammation (PTI) with Numerous Normal Hepatic Cells (NHC), as Well as Absence of Focal Necrosis.

Table 5: Effect of Moringa oleifera Leaf Extract on Histology of the Liver of Rats with $\mathrm{Ccl}_{4}$-Induced Hepatotoxicity

\begin{tabular}{ll}
\hline & LIVER \\
\hline & Normal architecture. \\
& No steatosis. \\
GP1 (Negative Control): & Mild Portal inflammation. \\
$10 \mathrm{ml} / \mathrm{kg} \mathrm{Normal} \mathrm{saline} \mathrm{only}$ & Mild Congested sinusoids. \\
& No necrosis. \\
& No fibrosis. \\
& Distorted architecture. \\
& Focal necrosis \\
$\mathrm{GP} 2: 10 \mathrm{ml} / \mathrm{kg}$ of Normal saline & Severe steatosis. \\
$+3 \mathrm{ml} / \mathrm{kg} \mathrm{CCl}$ (Induction or $_{\text {Toxic control) }}$ & Severe Portal inflammation with interphase hepatitis \\
& Severe Congested sinusoids. \\
& No fibrosis. \\
& Improving architecture compared to GP2 \\
\hline
\end{tabular}




\begin{tabular}{|c|c|}
\hline GP3: $100 \mathrm{mg} / \mathrm{kg}$ Silymarin +3 & Decreased steatosis. \\
\hline \multirow[t]{6}{*}{$\mathrm{ml} / \mathrm{kg} \mathrm{CCl}_{4}$ (Reference control) } & Decreased Portal inflammation but no interphase hepatitis. \\
\hline & Mild to moderate Congested sinusoids. \\
\hline & Decreased necrosis. \\
\hline & No fibrosis. \\
\hline & Mildly distorted architecture. \\
\hline & Mild focal necrosis. \\
\hline GP4: $9 \mathrm{mg} / \mathrm{kg}$ Extract $+3 \mathrm{ml} / \mathrm{kg}$ & Mild to moderate steatosis in less than $25 \%$ of cases. \\
\hline $\mathrm{CCl}_{4}$ & Mild Portal inflammation. \\
\hline \multirow{3}{*}{ ( Test I) } & No fibrosis \\
\hline & Mildly distorted architecture. \\
\hline & Nil focal necrosis. \\
\hline GP5: $18 \mathrm{mg} / \mathrm{kg}$ Extract $+3 \mathrm{ml} / \mathrm{kg}$ & Mild Microvesicularsteatosis in less than $10 \%$. \\
\hline $\mathrm{CCl}_{4}$ & Moderate Portal inflammation. \\
\hline \multirow[t]{3}{*}{ ( Test II) } & Mild Congested sinusoids. \\
\hline & No fibrosis \\
\hline & Mildly distorted architecture. \\
\hline GP6: $27 \mathrm{mg} / \mathrm{kg}$ Extract $+3 \mathrm{ml} / \mathrm{kg}$ & Mild Microvesicularsteatosis in less than $10 \%$. \\
\hline $\mathrm{CCl}_{4}$ & Nil Portal inflammation. \\
\hline (Test III). & Mild Congested sinusoids. \\
\hline & No fibrosis \\
\hline Remarks & $\begin{array}{l}\text { The reference control has mild to moderate hepatoprotective properties. The hepatoprotective properties of the ex- } \\
\text { tract increase with increasing doses of the extract. The extract has appreciable protective hepatic effect at the three } \\
\text { graded doses. }\end{array}$ \\
\hline
\end{tabular}

\section{Discussion}

This study was undertaken to evaluate the hepatoprotective effect of the methanolic leaf extract of Moringa oleifera in carbon tetrachloride $\left(\mathrm{CCl}_{4}\right)$-induced liver injury in albino Wistar rats.

The phytochemical analysis of MLE showed that it contains flavonoids, tannins, saponins, alkaloids, phlebotomines, terpenes and cardiac glycosides. Free and combined anthraquinones were absent. This was similar to the result obtained by Mishra et al., 2011. Assessment of liver function can be made by estimating the activities of serum ALT, AST, ALP and Bilirubin, which are enzymes originally present higher concentration within cytoplasm. When there is hepatopathy, these enzymes leak into the blood stream in conformity with the extent of liver damage (Suman et al., 2011). Bilirubin is one of the most useful clinical pointers to the severity of necrosis, and its accumulation is a measure of the binding, conjugation and excretory capacity of hepatocytes (Manokaran et al., 2008.

From the results of the biochemical analysis of this study, it was observed that administration of $\mathrm{CCl}_{4}(3 \mathrm{ml} / \mathrm{kg})$ alone caused a significant increase $(\mathrm{p}<0.05)$ in serum levels of ALT, AST, ALP and bilirubin (total and conjugated). Treatment with MLE (9, 18 and $27 \mathrm{mg} / \mathrm{kg}$ ) reversed the altered levels to near normal, in a dosedependent manner. It was compared with standard Silymarin $(100 \mathrm{mg} / \mathrm{kg})$. This is similar to the work of Kshirsagar et al., 2009. Results of histopathological studies provided supportive hepathoprotective evidence for biochemical analysis. Phytochemical analysis of the extract showed the presence of flavonoids. Flavonoids have been well documented as good hepatoprotective agents because they can effectively inhibit lipid peroxidation, scavenge free radicals and antioxidant enzyme activities (Potapovich et al., 2003). The DPPH free radical scavenging studies showed that MLE has antioxidant property. DPPH is a stable radical that has been used widely to evaluate the antioxidant activity of various natural products (Singh et al., 2011). In this study the 60\% methanol leaf extract of Moringa oleifera gave a concentrationdependent free radical scavenging activity.

\section{Conclusion}

It can be concluded based on our findings that methanolic leaf extracts of Moringa oleifera possesses antioxidant and hepatoprotective activities in a dose - dependent manner and safe for oral administration.

\section{References}

[1] Blois M.S. (1958). Antioxidant determination by use of a stable free radical. Nature; 26: 1199-1200

[2] Chatterjee, T. K. (2000). Medicinal Plants with Hepatoprotective Properties in Herbal Options. Books \& Allied (P) Ltd, Calcutter; 3:135.

[3] Dongare P.P., Dhande S.R., Kadam V.J. (2013). Standardization of Carbon tetrachloride-Induced Hepatotoxicity in Rats. Amr. J. Pharm Tech Res. 3(5).

[4] Ganatra T. J., Joshi U. H., Bhalodia P.N., Desai T. R., Tirgar P.R. (2012). A Panoramic view on Pharmacognostic, Pharmacological, Nutritional, Therapeutic and Prophylactic value of Moringa oleifera Lam. IRJP.3 (6)

[5] Goyal B.R., Agrawal B.A., Goyal R.K., Mehta A.A. (2007). Phytopharmacology of Moringa oleiferaLam.Ó An overview. Natural Product Radiance, Vol. 6(4), pp.347-353.

[6] Gupta, A. K., Misra, N. (2006). Hepatoprotective Activity of Aqueous Ethanolic Extract of Chamomile capitula in Paracetamol Intoxicated Albino Rats. American Journal of PharmTech Research 1(1): 17-20.

[7] Kshirsagar, A., Purnima, A.,Ingawale, D., Vyawahare, N., Ingale, K., Hadambar, A. (2009). Antioxidant and Hepatoprotective Activity of Ethanolic extract of Calotropisgigantea against Paracetamolinduced Liver Damage in Mice. Journal of Cell and Tissue Research. Vol. 9(2): pp 1859-1864.

[8] Manokaran, S., Jaswanth, A., Sengottuvela, S., Nandhakumar, J., Duraisamy, R., Karthikeyan, D., Mallegaswari, R. (2008). Hepathoprotective Activity of Aervalanata Linn. Against Paracetomol-induced Hepatotoxicity in Rats. Research Journal of Pharmacy and Technology 1(4): pp 398-400.

[9] Mishra G. et al.,(2011). "Traditional uses, phytochemistry and pharmacological properties of Moringa oleifera Plant: an overview", Scholars Research Library, Der Pharmacia Lettre, 3(2): 141 164

[10] Panda, B. B., Gaur, K., Nema, R. K., Sharma, C. S., Jain, A. K. Jain, C. P. (2009). Hepatoprotective activity of Jatrophagossypifolia against Carbon tetrachloride-induced hepatic injury in rats. Asian Journal of Pharmaceutical and Clinical Research, 2(1): 5054.

[11] Paramveer, D., Mishra, C., Rani, A., Shrivastava, B., Rajesh, K. (2010). Effective Alternative Methods of $\mathrm{LD}_{50}$ help to Save Number of Experimental Animals. Journal of Chemical and Pharmaceutical Research, 2(6): 450-453.

[12] Potapovich, A. I. and Kostyuk, V. A. (2003). Comparative study of antioxidant properties and cytoprotective activity of flavonoids. J. Biochem. 68(5):514-519

[13] Singh, A., Tejk, B., Sharma, O. (2011). Clinical Biochemistry of Hepatotoxicity. Journal Clinical Toxicology.http://dx.doi.org/10.4172/2161-0495.54-001. 
[14] Singh, S., Thomas, M. B., Singh, P., Bhowmik, D. (2013). Plant used in hepatoprotective remedies in traditional indian medicine. Indian journal of research in pharmacy and biotechnology. Vol. 1, issue 1, pp. 58-63.

[15] Suman P., Siva S. N., Durga P.P., Subas C.D., Vikas S., Amol J. (2011). Hepatotoxicity Activity of Crude Flavonoids Extract of Cajanusscarabaeoides (L) in Paracetamol Intoxicated Albino Rats.

[16] Trease G.E. and Evans W.C. (2002). Pharmacognosy. $15^{\text {th }}$ Ed. London: Saunders Publisher. Pp 42-44, 221-229, 246-249,304-306, 331-332, 391-393 